\title{
Linguistic Verbal Arts and the Problem of Overpopulation Growth in Nigeria
}

Òpọọlá Bọ́láńlé Tajudeen*

Federal University, Oyẹ-Ėkitì, Nigeria

Corresponding Author: Òpọọlá Bọ́láńlé Tajudeen, E-mail: dropoola59@gmail.com

\section{ARTICLE INFO}

Article history

Received: January 25, 2019

Accepted: April 21, 2019

Published: June 30, 2019

Volume: 10 Issue: 3

Advance access: May 2019

Conflicts of interest: None

Funding: None

Key words:

Population,

Verbal Arts,

Religion,

Oracle,

Tradition,

Procreation,

Information

\begin{abstract}
Linguistic verbal arts deals with the use of chants, statements and verses of oral and written materials in expressing feelings using one language or the other. Among the challenges militating against expected human and material development in many African countries is population explosion. Available social infrastructures can no longer adequately satisfy the needs of the people. At present, in Nigeria compared with what obtained many years ago, religious practices are taken as excuses for marrying many wives when in the actual sense, there are often misinterpretations of the doctrines of the religions. The findings of this paper is that though many Nigerians are either Muslims or Christians with few number of traditional religious faith, the lust for marrying more than one wife did not make them obey the doctrines of their religious practices. This paper derives its strength from collation of verbal arts as expressed in the Holy Books of the Muslims, Christians and Ifá Oracle, one of the African traditional religions. The paper posits that no religion in Nigeria advocates for many wives and many children. The implication of this paper among others is that it provides valuable information on Nigerian population particularly as this concept remains a great troubling issue for Nigerian and many African governments. It is yet an attempt aimed at discouraging Africans from creating more problems for themselves and the continent through production of more children than they can cater for.
\end{abstract}

\section{INTRODUCTION}

In African child upbringing as enshrined in African education, references are usually made to relevant verses in African religions. There are verses that teach moral and decent ways of life. In Nigeria, adoption of foreign religions like Islam and Christianity is one of the consequences of European and Arab colonization. The northern pre independent Nigerians were introduced to Islamic religion while the southern ones embraced Christianity though few Nigerians are still with African traditional religions. Issues of population and population explosion have attracted the attention of some researchers and government policies makers in several countries of the world (see Ruzicka and Kane, 1986; Preston and Donaldson, 1986; Ogunbiyi, 2012; Odeyemi, 2017; https://www.tributeonlineng.com, November 1, 2018). For example, Preston and Donaldson (1986) submit that:

Since 1950, population growth rates in developing countries have averaged around 2 per cent per year, enough to double the size of a country's population in 35 years. The calculation is not merely hypothetical; the population of the developing world (Africa, Latin America and Asia, except Japan) has in fact doubled between 1950, when it numbered 1.7 billion and 1984 , when it reached 3.6 billion.
Ogunbiyi (2012) also reports that Nigeria is one of the 15 hot spots countries in Sub-Sahara Africa that is currently experiencing high rates of population growth. Globally too, Nigeria is said to be in the seventh position (see https://www.internetworld stats.com). To further confirm that there is population explosion in Nigeria, the Nigerian population with that of its colonial master from 1960 to 2018 is presented in Graphs 1, 2 and 3 below. The percentage of increase in every ten years especially between 1960 and 2010 is also shown in Table 1 below.

Still on the population increase, it has been predicted that between 2018 and 2050 at least 189 million people will be added to the existing population and as a result the projected Nigerian population will be around 400 million (see https: www.premiumtimesng.com, 17/5/2018). The uncontrollable population increase between 1960 and 2018 is now a source of concern and worry to the present Federal Government of Nigeria as shown below:

For some time now, there has been palpable worry in official circles over Nigeria's rising population figure. For instance, last week, Vice President Yemi Osinbajo and the Minister of Finance, Hajia Zainab Ahmed, speaking at the $24^{\text {th }}$ Nigerian Economic Summit in Abuja, expressed concern about the country's population. According to Osinbajo, the government is working to re- 


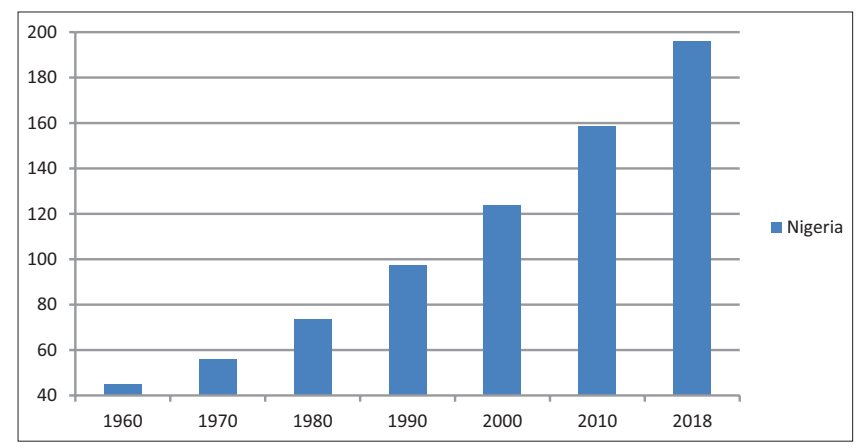

Figure 1. Nigeria Population in millions

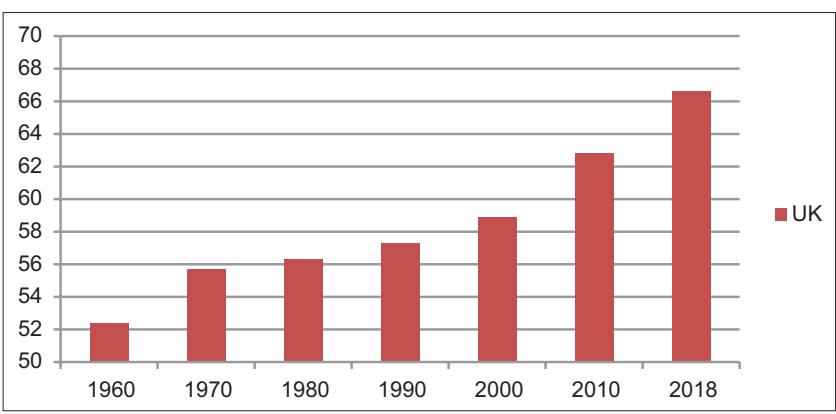

Figure 2. UK Population in Millions

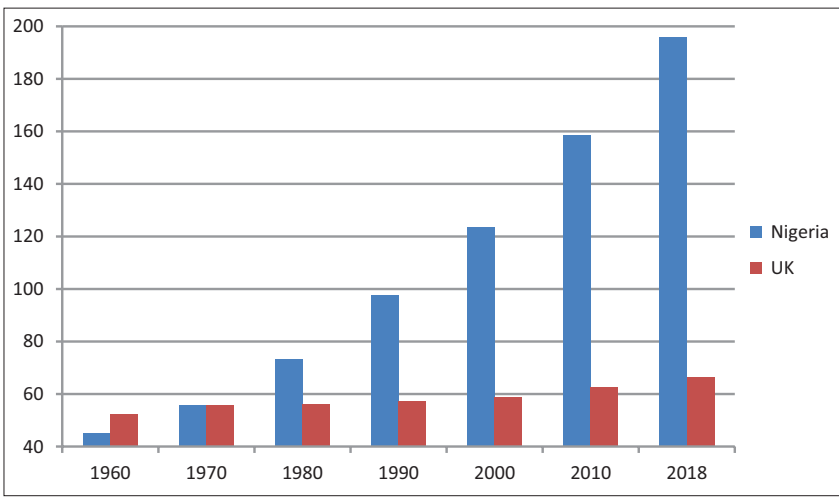

Figure 3. Comparing Nigeria and UK Population

Table 1. Percentage of increase in every 10 years

\begin{tabular}{lcc}
\hline Years & Nigeria (\%) & U.K. (\%) \\
\hline $1960-1970$ & 19.36 & 5.86 \\
$1970-1980$ & 23.79 & 1.15 \\
$1980-1990$ & 24.69 & 1.64 \\
$1990-2000$ & 21.12 & 2.78 \\
$2000-2010$ & 22.00 & 6.18 \\
$2010-2018$ & 19.03 & 5.71 \\
\hline
\end{tabular}

duce the country's population by half through education (see Nigerian Tribune Nov 1, 2018).

But, before the Federal Government of Nigeria embarks on its plan to reduce the Nigerian population by half through education, a plan that may not witness the light of the day or that the government has not disclosed the content of its proposed system of education, Michael and Odeyemi (2017: 109-111) identify seven factors that they claim are responsible for the current outrageous population of $\mathrm{Ni}$ - geria. The factors are multiculturalism, religion, illiteracy, inadequate resources, approach adopted in policies formulation, lack of political will and lack of incentive. However, at present and from the available evidence, there is no concrete measure that has been put in place to curb the Nigerian population explosion. In this paper, we submit that the teaching of Òyè̀kú Méjì, an Ifá verse, if adopted and put into use, will not only help to address the problem of population explosion in Nigeria but also in some other third world countries of the world where population growth has become a source of concern and worry.

\section{RESEARCH PROBLEMS}

African population has grown to alarming proportion to the extent that it is daily attracting the world attention in several ways. Over population in African Continent especially Nigeria has created hardship effects ranging $\mathrm{n}$ from hunger to almost all forms of misnomer attitudes of the adults and youths. Overpopulation in Nigeria is recently the basis for unemployment, hooliganism, armed robbery, and many other social disorder. This paper has identified the act of marrying more than one wife by many Nigerians as a major contributory factor for overpopulation in the country.

\section{Aims and Goals of the Research}

This research is intended to among others, enlighten Nigerian men on the need to morally and religiously positively contribute to population control in their own individual ways. This study is also to refer Nigerian men and women to moral instruction as in Islamic, Christian and Traditional religions using quotable quotes in these religions that discourage polygamous life that is responsible for over population.

\section{Collection and Interpretation of Data}

Several factors have been identified as factors that have been responsible for the present outrageous population increase in Africa (see Caldwell and Caldwell, 1987; Michael and Odeyemi, 2017). It has been argued that one of such factors is African traditional religion. Caldwell and Caldwell (1987: 427) say:

Traditional African religious values have sustained high fertility in two ways. First they have acted directly to equate fertility with virtue and spiritual approval and associate reproductive failure or cessation with sin. Second, they have placed both positive and negative sanctions on filial piety and maternal homage to the older generation so that fertility is rarely disadvantageous.

While we agree with Caldwell and Caldwell (1987: 427) that infertility in Africa is a serious issue we want to submit that infertility is traceable to women only though science has now shown that infertility can also be traced to men. However, one question which Caldwell and Caldwell (1987: 427) do not address is: Does fertility mean indiscriminate practice of polygamy and procreation abuse or indiscriminate procreation?

Similarly, we are of the opinion that lack of understanding of the Biblical and Quranic teachings or messages with 
reference to monogamy and polygamy is also the cause of the uncontrollable population growth in Nigeria. For example; the Bible can be divided into two sections namely Hebrew and Greek scriptures. Information from the Hebrew scriptures can be divided into two also. There are Biblical references that support monogamy or one man one wife. Such references include Genesis 2:18 where God created only Eve for Adam, Genesis 6:18 where Noah married only one wife and Genesis 19:15 showed that Lot had one wife to mention a few. But each of Abraham, David and Solomon had more than one wife (see Genesis 16:2-4; 2 Samuel 12:11; 1 King 11:3). However, Greek scriptures endorse one man one wife and not one man many wives (see Matthew 19:4-6; 1 Timothy 3:2). In short and from our research, although Christianity had become a religion in Nigeria since the year 1772, polygamy had also been part of the Christian practices until the newly founded autochthonous Nigerian Churches started to have influence over the teachings of the European Churches in the 1980s and 1990s (see also Jẹ́gẹdé, 2008; Ìkòtún, 2013). However, that the teachings of the newly founded autochthonous Nigerian Churches are slightly different from that of the European Churches a few Christians, using the examples of Abraham, David and Solomon in the Bible, still engage in polygamy.

Still on the contribution of Islam and Christianity to the population explosion in Nigeria, what is the case among some Christians is also the case among some Muslims. There are instances where a Muslim marries four wives and such a Muslim claims to draw inspiration from the Holy Quran Chapter 4 Verse 3, where it is recorded thus:

If ye fear that ye shall not be able to deal justly with the orphans, marry women of your choice, two or three or four, but if ye fear that ye shall not be able to deal justly (with them), then only one, or (a captive) that your right hands possess, that will be more suitable, to prevent you from doing injustice (see The Holy Quran chapter 4:3).

With this Quranic verses the following questions came to mind: Is it expressly stated from this verse that a man can marry four wives? Is it possible for a man to be just among four women? Unless these two questions are answered, we will insist that so many Muslims who engage in polygamy do not have any reference in the Holy Quran to support their actions. We can defend the fact that those who embrace polygamy are only guided by their lust.

Another deduction from Caldwell and Caldwell (1987: 427) is procreation with reference to the number of children a couple can produce or have. It will be observed that when population explosion is being discussed the role procreation plays cannot be ignored. There are several examples where some individual Christians and Muslims have 6 or 7 or 8 or 9 children at least in some cases especially among Muslims and some members of the European Churches. The question that arises is: Does the Holy Quran with the Holy Bible prescribe the number of children a couple can have? The answer is no. But, an injunction that is recorded in 1 Timothy 5:8-9 which says "Certainly if anyone does not provide for those who are his own and especially for those who are members of his household, he has disowned the faith and is worse than a person without faith" is, in most cases, not considered by many Christians. Instead, they do say "God is the One that provides and is the One that takes care of us. Just believe in Him, He will provide". The sentence "believe in God" which shows a strong union between Muslims and Christians is responsible for the indiscriminate procreation among the two groups and especially among Muslims.

Furthermore, the indiscriminate procreation among Nigerians as a result of the sentence "believe in God" reminds us of what Muhammand Sanusi II, the Emir of Kano, says:

We talk about miracles, ancient miracles. I don't like the word miracles because they are associated with angels with wings that you do not see, coming from the sky. The Chinese are human beings like us and they did it. When we say miracle, it sounds like something supernatural that has some certain powers to it. Every time you think about it, the only deficit we have is a policy deficit... So, for all Nigerians, who care about this country, the real task before us is to know that we have 30 years on the outside in which we need to make sure that we do not become the poverty capital of the world, and slum of the world. Earlier in 2018, Nigeria overtook India to become the poverty capital of the world. According to British prime minister Theresa May, 87 million Nigerians are living below the poverty line.

In addition to the information given by Sanusi and May several State and Federal government workers have not been regularly paid in the last three years despite the monthly allocations, bailout funds, Paris Club loan refund and Abacha loot. In fact, some States are still owing their workers six or more than a year salaries. We want to remind the Nigerian Muslims and Christians that faith without works is dead. In other words, the current situation in Nigeria has shown that the word 'belief' as it is embraced by Nigerian Muslims and Christians is not beneficial unless it is accompanied by Allah's or God's wisdom. Therefore, in view of the information in Graphs 1 and 3 and Table 1 in the introductory section of this paper where Nigerian population has been on the increase in the last forty years especially when Islam and Christianity can be said to be dominant in Nigeria, we submit that Islam and Christianity are responsible for the current population explosion and not the Traditional African religion as advanced by Caldwell and Caldwell (1987: 427). In this paper, we show that if the message contained in Òyè kú Méjì, an Ifá verse, a Traditional African religion that is now practised in Cuba, Brazil and Trinidad and Tobago, is adopted and put into use by the Federal Government of Nigeria as well as other third world countries, it will help to address population explosion that is, at present, a source of concern.

Another area of interest to the present research is what Michael and Odeyemi (2017: 109-111) call lack of political will on the part of the various governments in Nigeria to put in place measures that can help to monitor and check uncontrollable population growth. The researchers argue that:

Lack of political will is a challenge to the effectiveness of the policies. This occurs most where the government in power does not have population growth control in its manifesto or agenda. The consequence of this becomes lack of both financial and administrative support. Where fund is at all allocated to the policies implementation, the 
bureaucratic nature of government and corruption among the implementers caused delays in implementation...

We agree with Michael and Odeyemi (2017: 109-111) that since 1953 when Nigeria was granted self rule by its colonial master and now there has not been any political party that has population growth control in its manifesto or agenda. What the political parties have are programmes or manifestoes such as free education, free water, free roads and jobs for all to mention a few which can mesmerize the voters and are manifestoes that encourage indiscriminate practice of polygamy and indiscriminate procreation. In fact, it can be said that between 1953 and now, a reasonable number of the Nigerian leaders as well as many who have been in the position of authority might have lost count of the number of wives as well as children they have. Therefore, what the leaders do not have there is no way they can give it. So, that the present federal government of Nigeria is talking about reducing the population of Nigeria by half does not mean it has the issue in its manifestoes but because some international bodies and individuals are talking about the danger Nigeria is facing vis-a-vis its population growth that is why the government is talking too. Even now that seventy three political parties are campaigning for the 2019 general elections it is disheartening to observe that no single political party is talking about population growth control. In this paper, we submit that it is high time the Nigerian government emphasized the need to promote population growth control in its manifestoes and that it can only do that not with the help of Islam and Christianity as they are practised in Nigeria but with the help of the Traditional African religion with reference to Ifä that is indigenous to us.

The data from Yoruba traditional religion were drawn from verse 6 lines 29 to 52 of Òyẹ̀kú Méjì, a sub-section of Ifá, are examined in this paper. In Yorùbá culture, Ifá is regarded as a repository of the people's culture, history, tradition and values (see Abimbola, 2006). We wish to submit also that most Yorùbá wise sayings are drawn from Ifá and that some of the wise sayings are used in Yorùbá songs and in day-to-day language use in social interactions among the Yorùbá people.

In this section, we present our data that are taken from Òyè̀kú Méjì, an Ifá verse. We implore our readers to carefully note the difference between the information in line one and the information in other lines.

Òyè̀kú Méjì

...Ọ̀kan șoșo póró lobìnrín dùn mọ lọ́wọ́ ôkọ,

Bí nwọn bá di méjì,

Nwọn a dòjòwú.

Bí nwọn bá di mẹ́ta,

Nwọn a dẹta ǹtúlé.

Bí nwọn bá di mẹrin,

Nwon a di ìwo lo rín mi ni mo rín o.

Bí nwọn bá di márùún,

Nwọn a di lágbájá ní ó run ôkọ wa tán lóhun susuusu.

Bí nwọn bá di mẹ́à,

Nwọn a dikà.

Bí nwọn bá di méje,

Nwọn a dàjé.

Bí nwọn bá di mẹjọ,

Nwọn a di ìyá alátàrí bàmbà
Ló ti kó irú èyí se okọ wa lọ́wọ.

Bí nwọn bá di mẹsàán,

Nwọn a di ìyáálée wa ò níșẹ kan.

Kò lábọ̀ kan,

Bó bá ti jí,

Așo okọọ wa níi máaá sán kiri.

Bí nwơn bá di mẹ́wàá,

Nwọn a di ilé ni ôkọo wá jókòó

Ni nwọ́n ńwá ôkọọ waá wá...

\section{English Translation}

The two 'oyeku'

Only one wife is ideal for a good home

When they are two

They become competitors

When they are three

The home is scattered

When they are four

They become touch me not

When they are five

They suspect one another

When they are six

They become heartless

When they are seven

They become witches

When they are eight

They become unruly

With nine wives

They become gossipers

When they are ten

They discuss carelessly

The information in verse 6 lines 29-52 in the data above can be divided into two. The message in verse 6 line 29 shows the importance and beneficial nature of monogamy or one man one wife. The use of the phrase "șoșo póró"(only) emphasizes one wife only. The information in verse 6 lines 30-52 shows that more than one wife must be discouraged and that there is no argument that can be advanced in its favorr. Again, the consequences of marrying more than one wife which include envy in line 31 , disorganization in line 33, wickedness in line 39 and witchcraft in line 41 as shown in the Data above also confirm the Yorùbá saying and the saying is: Ilé olórogún ogbà wèrè ni (A polygamous house is not different from that of the mad people). But, does verse 6 line 29 which insists on one man one wife discuss procreation abuse? Our answer is yes. This is because the Yorùbá people say: "Omọ bẹere òsì bẹerẹ" (Many children much poverty). Therefore, if the teachings of Islam, Christianity and Ifá, the African religion that has a reference book, are clearly under-

35 stood and religiously embraced the Nigerian population explosion that is being witnessed today would not have arisen.

\section{CONCLUSION}

40 In this research, attention was focused on the need to establish family control through religious preaching at Nigerians various religious programs as it has been established that both the foreign and African traditional religions em- 
phasize monogamous ways of life. The study posits that in complementing the medical enlightenment on the negative effects of overpopulation, reference to the verses of Muslims holy Quran, Christian holy bible and Ifa corpus should also be used to discourage the Nigerian men from hiding under religious doctrines in marrying more than one wife and contributing to overpopulation in Nigeria.

\section{REFERENCES}

Abimbola, W. (2006) İjìnlè Ohùn Ẹnu Ifá (Apá kín-ìn-ní). Ibadan: University Press Plc https: www.premiumtimesng.com, 17/5/2018 https://www.tributeonlineng. com, November 1, 2018.

Ikotun, R. O. (2013) 'New Trends in Yorùbá Personal Names among Yorùbá Christians". Linguistik Online, 59(2), 67-85.

Jegede, G. G. (2008) The History of the Aladuura Churches in Ekiti Land, 1925-2005. PhD. Thesis, University of Ado-Ekiti, Nigeria.
Michael, T. O. and M. A. Odeyemi (2017) "Nigeria's Population Policies: Issues, Challenges and Prospects". Ibadan Journal of the Social Sciences, 15(1), 103-115.

New World Translation of the Holy Scriptures 1984, Watchtower Bible and Tract Society of New York INC.

Ogunbiyi, B. (2012) Nigeria: Population and Demographic Trends. The Woodrow Wilson International Center for Scholars, Washington DC.

Population Pyramids of the World from 1950 to 2100. Available online at populationpyramid.net/nigeria/1960

Preston, Samuel H. and Peter Donaldson (1986) Population Growth and Economic Development. Asia-Pacific Population Journal, 1(2), 3-12.

Ruzicka, L. T., and Kane, P. S. (1986) Mortality and Development in the ESCAP Region: A Review. Asia-Pacific Population Journal, 1(2), 13-38.

The Holy Quran, Text, Translation and Commentary 1983. America: Amana Corporation. 